\title{
Analysis on Education Spending Per Student in OECD Main Countries*
}

\author{
Lizhen Jin \\ School of Marxism \\ Tianjin University of Technology \\ Tianjin, China
}

\author{
Rui Chen \\ School of Social Development \\ Tianjin University of Technology \\ Tianjin, China
}

\begin{abstract}
Since the 21st century, all countries in the world have continuously increased investment in education, increased spending on education, and adjusted the optimal allocation of educational resources in order to enhance their international competitiveness. This paper selects and analyzes annual spending per student on educational institutions for all services and annual expenditure per student on educational institutions for different types of services which are both in the four levels of primary education, secondary education, post-secondary non-tertiary education and tertiary education from 19 countries in the OECD in 2014. The results showed that: most countries put their funds into tertiary education, while neglecting post-secondary non-tertiary education; the funding investment for primary education and secondary education are huge. How to make a reasonable and optimal allocation of education expenditure is an important issue which is worth of attention.
\end{abstract}

Keywords-OECD; education expenditure per student; investment in education

\section{INTRODUCTION}

As a highly researched value result in OECD, its official publication, Education at a glance is very forward-looking, practical and accurate. [1] Some domestic scholars have studied the OECD education indicators, data of education funding indicators and education spending system. Ji-Hong Sun and Xiao-Jiang Yang (2009) studied the origin, basis theory and framework of OECD education indicators.[2] Min-Juan Xu (2011) interpreted and deeply analyzed education funding and other aspects of OECD education indicators in South Korea, the United States, France, Germany and Japan in 2009. She also explained the trend and characteristic of OECD education indicators.[3] Ying Ding (2008) took the Un ited States, Japan, France, Germany, the United Kingdom and South Korea as the research objects and used the statistics of the Organization for Economic Cooperation and Development in 2003, from many perspectives of funding sources on public education institutions and private education institutions so as to analyze the characteristics and determinants of public and private education in various countries.[4] Chu-Hui Liao (2004) compared the educational spending system in the western developed countries. He listed the advantages and

*This research was financially supported by the Tianjin philosophy and social science research program (Project No.: TJJX16-005). disadvantages of various educational finance systems, as well as common features and development trends.[5] Xiang Zhao (2007) analyzed the education expenditure performance evaluation model in the United Kingdom, the United States and Japan, and then he proposed the inspiration of our educational expenditure pattern in our country. He believed that China must establish a clear goal and a complete systemof institutions. [6]

This paper uses education expenditure per student from the OECD education indicator so as to effectively analyze and evaluate the educational funding level of a country. On the basis of previous research, the paper uses the annual spending per student on educational institutions for all services and annual expenditure per student on educational institutions for different types of services in 19 OECD countries available for primary education, secondary education, post-secondary non-tertiary education (secondary vocational education, upper secondary vocational education and training as well as college preparatory studies) and tertiary education levels, and then combines with the OECD average in Excel descending order. Thus, the paper discovers the characteristics of per student spending in these countries at different levels of education.

\section{RESEARCH DATA}

TABLE I. ANNUAL SPENDing Per StUdent on EdUCATIONAL INSTITUTIONS FOR ALL SERVICES IN 2014 (UNIT, USD)

\begin{tabular}{|l|l|l|l|l|}
\hline Country & $\begin{array}{l}\text { Primary } \\
\text { education }\end{array}$ & $\begin{array}{l}\text { Secondary } \\
\text { education }\end{array}$ & $\begin{array}{c}\text { Post- } \\
\text { Secondary } \\
\text { Non-Tertiary } \\
\text { Education }\end{array}$ & $\begin{array}{c}\text { Tertiary } \\
\text { Education }\end{array}$ \\
\hline Australia & 8251 & 11023 & 5963 & 18038 \\
\hline Austria & 11154 & 15094 & 4817 & 16933 \\
\hline $\begin{array}{l}\text { Czech } \\
\text { Republic }\end{array}$ & 5101 & 8191 & 2428 & 10521 \\
\hline Estonia & 6760 & 7077 & 8014 & 12375 \\
\hline France & 7396 & 11815 & 9736 & 16422 \\
\hline Germany & 8546 & 11684 & 10646 & 17180 \\
\hline Hungary & 3789 & 6104 & 9855 & 8688 \\
\hline Iceland & 11163 & 10078 & 12336 & 11435 \\
\hline Ireland & 8007 & 10665 & 11359 & 14131 \\
\hline Israel & 6833 & 6699 & 2380 & 12989 \\
\hline Latvia & 6585 & 6629 & 8357 & 8962 \\
\hline Luxembourg & 21153 & 21595 & 1364 & 46526 \\
\hline Netherlands & 8529 & 12446 & 11313 & 19159 \\
\hline
\end{tabular}




\begin{tabular}{|l|l|l|l|l|}
\hline Country & $\begin{array}{l}\text { Primary } \\
\text { education }\end{array}$ & $\begin{array}{l}\text { Secondary } \\
\text { education }\end{array}$ & $\begin{array}{c}\text { Post- } \\
\text { Secondary } \\
\text { Non-Tertiary } \\
\text { Education }\end{array}$ & $\begin{array}{l}\text { Tertiary } \\
\text { Education }\end{array}$ \\
\hline New Zealand & 7438 & 10267 & 10019 & 15088 \\
\hline Norway & 13104 & 15149 & 15979 & 20962 \\
\hline Poland & 7026 & 6455 & 3950 & 9708 \\
\hline $\begin{array}{l}\text { Slovak } \\
\text { Republic }\end{array}$ & 6235 & 6453 & 7590 & 11290 \\
\hline Sweden & 10804 & 11342 & 4313 & 24072 \\
\hline United States & 11319 & 12995 & 15086 & 29328 \\
\hline $\begin{array}{l}\text { OECD } \\
\text { Average }\end{array}$ & 8733 & 10106 & 8184 & 16143 \\
\hline
\end{tabular}

As "Table I" and "Fig. 1" shown, because the annual spending per student on post-secondary non- tertiary education institutions in some countries is included in the data of lower secondary educational institutions or other educational institutions, based on the availability of data, the paper chooses average annual expenditure per student in 19
OECD countries for primary education, secondary education, post-secondary non-tertiary education and tertiary education. The statistical method is as follows: the expenditure per student in a given educational institution is equal to the total expenditure of educational institutions at this level divided by the corresponding equivalent number of full-time students The number of educational institutions and courses which is available to data of students and their expenditure is counted. This data is divided by the GDP Purchasing Power Parity Index, and the local currency is converted to the equivalent U.S. dollar. Expenditure on education involves spending on public and private education institutions for all services, including core education services, ancillary services and research and development activities provided by educational institutions. All data which is used in the paper are from the OECD official publication, Education at a glance: 2017 OECD indicators ${ }^{[7]}$.

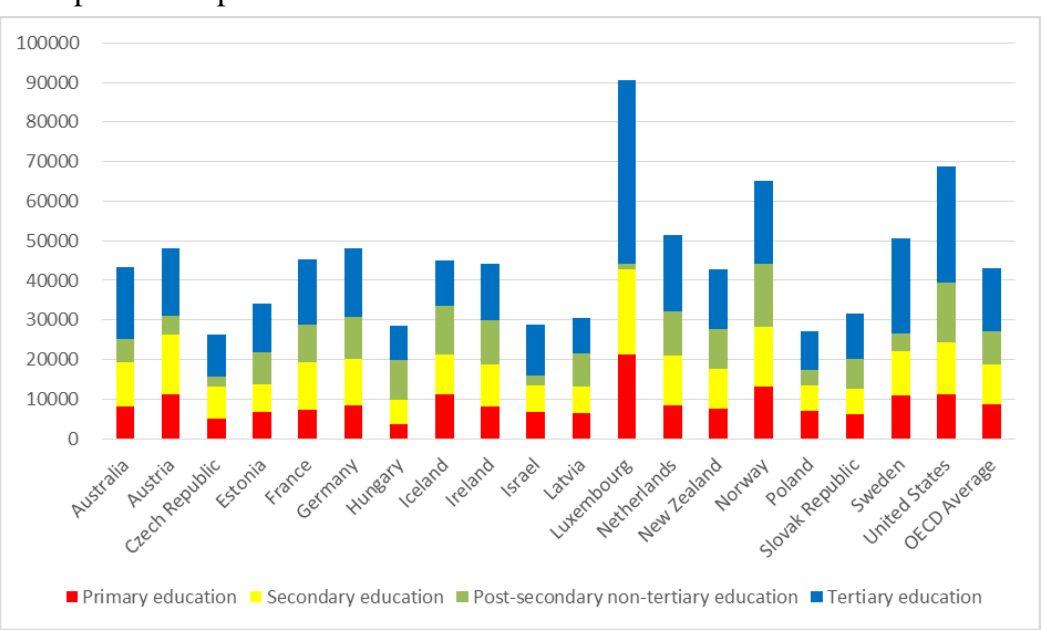

Fig. 1. Annual expenditure per student on educational institutions for all services in 2014 .

\section{ANALYSIS FOR DAT A}

\section{A. Analysis for Annual Spending per Students on Different Level Educational Institutions}

In some OECD countries, even though the expenditure per student from primary education to tertiary education is very close, the distribution of resources among countries at different education level is still quite different. On average, just as "Table I" shown, OECD countries spend $\$ 8,733$ in primary education level, $\$ 10,066$ in secondary education level, $\$ 8,184$ in post-secondary non-tertiary education level and $\$ 16,143$ in tertiary education level.

1) Analysis for annual spending per students on primary educational institutions: Primary education is the first stage of basic education. Students in the level are mainly educated reading, writing, math and other basic education. The admission age of its educate is generally 5-7 years old, and this schoolsystemis 6 years.

As can be seen from "Fig. 2", in the 19 countries where the data is available in paper, the difference concerning spending per student in primary education is about sixtimes, from Slovak Republic, Czech Republic and \$3,789 in Hungary to the United States, Norway and \$21,153 in Luxembourg. Spending per student on primary education in Luxembourg, Norway, the United States, Iceland, Austria and Sweden is above the OECD average level. On the contrary, spending per student on primary education in Germany, the Netherlands, Australia, Ireland, New Zealand, France, Poland, Israel, Estonia, Latvia, Slovak Republic, Czech Republic and Hungary is all below at the OECD average level. At this education level, for example, teachers' salaries in Hungary and other countries are very low, to some extent, which led to low spending per student on primary education. 


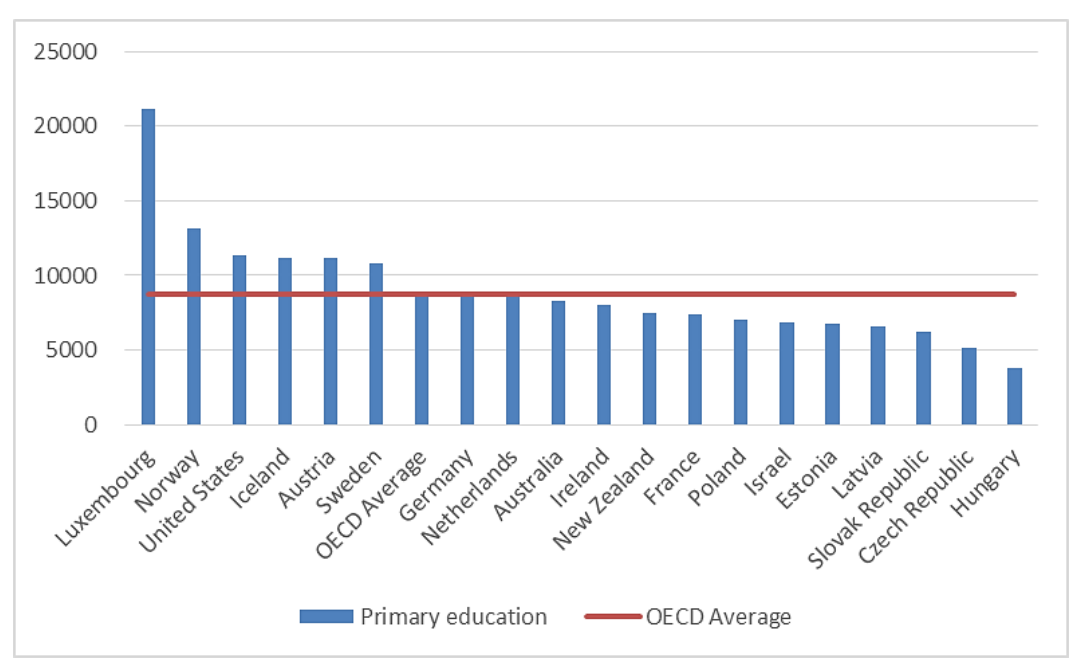

Fig. 2. Sort out annual expenditure per student on primary educational institutions for all services in 2014.

2) Analysis for annual spending per students on secondary educational institutions: Secondary education includes lower secondary education and upper secondary. Lower secondary education is the second stage of basic education. Students in this level are mainly educated subject teaching. The admission age of its educatee is usually 12 years old, and the education system is 3 years. In countries with compulsory education systems, upper secondary education generally begins after full-time compulsory education is completed. The admission age of its educatee is usually 15 or 16 years old, and the school system is generally 3 years.

As can be seen from "Fig. 3', in the 19 countries where the data is available in this paper, the difference concerning spending per student in secondary education is about four times, from Poland, Slovak Republic and \$ 6104 in Hungary to Austria, Norway and over $\$ 20,000$ in Luxembourg. Spending perstudent on secondary education in Lu xe mbourg, Norway, Austria, the United States, the Netherlands, France, Germany, Sweden, Australia, Ireland and New Zealand is above the OECD average level; spending per student on secondary education in Iceland, the Czech Republic, Estonia, Israel, Latvia, Poland, Slovak Republic and Hungary is below the OECD average level. On average, expenditure per student in secondary education is about 1.2 times higher than that in primary education. The main reason is that the number of student class hours from primary education to secondary education increases.

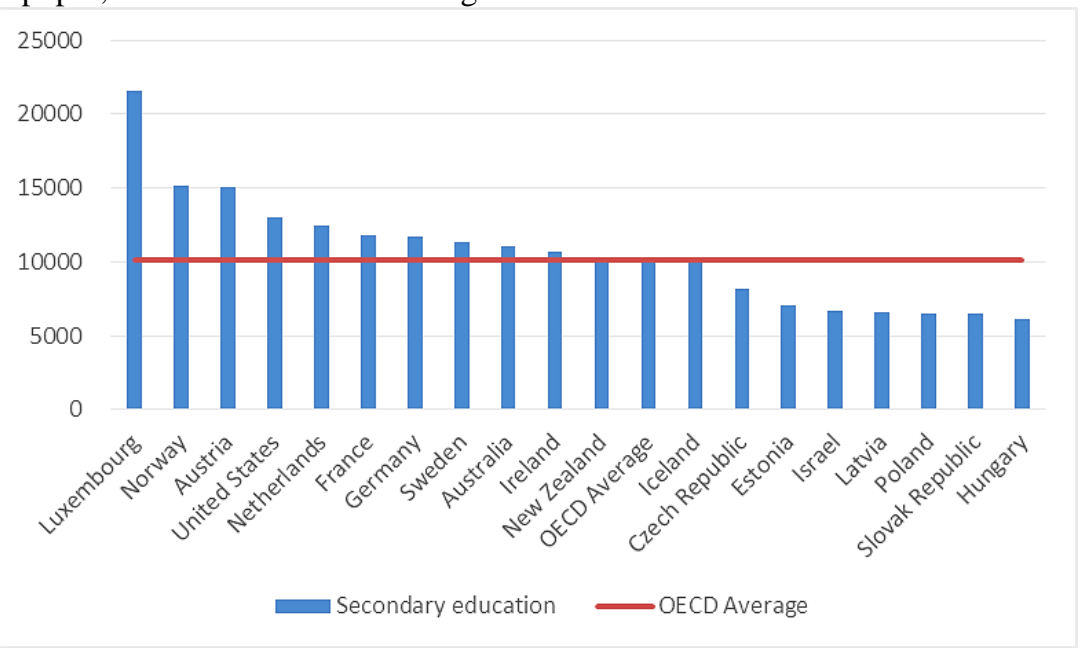

Fig. 3. Sort out annual expenditure per student on secondary educational institutions for all services in 2014 .

3) Analysis for annual spending per students on postsecondary non-tertiary educational institutions: Postsecondary non-tertiary education generally refers to vocational education or college preparatory. In accordance with the ISCED, internationally, this level spans high school education and post-secondary education. Some countries treat this education level as high school, while others regard it as post-secondary education. The admission age of its educatee is higher than the age of high school. The school systemis usually 6 months to 2 years of full-time study.

As can be seen from "Fig. 4", in the 19 countries where data is available in the paper, the difference in spending per student on post-secondary non-tertiary education is about 12 times, from the Czech Republic, Israel and $\$ 1,364$ in 
Luxembourg to Iceland, the United States and \$ 15,979 in Norway. Spending for post-secondary non-tertiary students in Norway, the United States, Iceland, Ireland, the Netherlands, Germany, New Zealand, Hungary, France and Latvia is above the OECD average level; the post-secondary non-tertiary expenditure per student in Estonia, Slovak Republic, Australia, Austria, Sweden, Poland, the Czech Republic, Israel as well as Luxembourg is below the OECD average level.
In Luxembourg, spending per student in primary, secondary education and tertiary education are in the forefront, but spending per student in post-secondary nontertiary education is at the bottom. From a microscopic point of view, this is related to the higher salaries of teachers who employed in Luxembourg for more than 15 years. And this is also closely connected to low teacher-student ratio. However, from a macroscopic point of view, the Luxembourg government places a high value on tertiary education in prioritizing the allocation of financial resources.

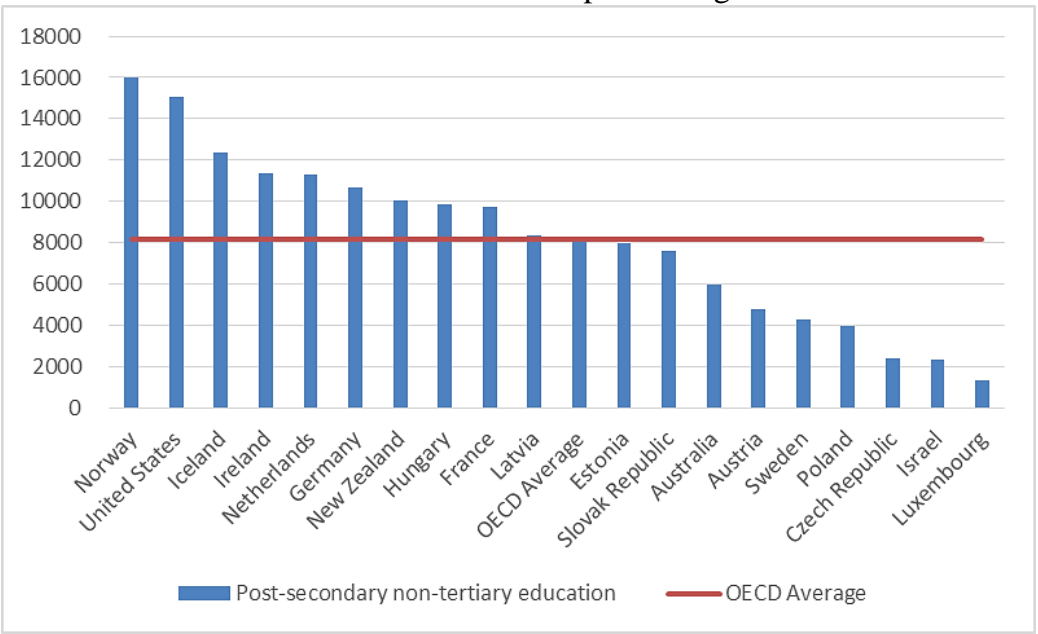

Fig. 4. Sort out annual spending per student on post-secondary non-tertiary educational institutions for all services in 2014 .

4) Analysis for annual spending per students on tertiary educational institutions: According to the International Standard Classification of Education, higher education includes A and B categories. Category A higher education is basically theoretical education, which qualifies for graduate education. The shortest education system is full-time 3 years. It can also be 4 years or longer. Category $\mathrm{B}$ higher education focuses on the practicality of employment skills. Its shortest schoolsystemis full-time 2 years.

As can be seen from "Fig. 5", in the 19 countries where data is available in paper, the difference in expenditure per student in tertiary education is five times. From Poland, Latvia and \$ 8,688 in Hungary to Sweden, the United States and $\$ 46,526$ in Luxembourg. In higher education level, spending per student in Luxembourg, the United States, Sweden, Norway, the Netherlands, Australia, Germany and Austria is higher than OECD average level. The tertiary education expenditure per student in New Zealand, Ireland, Israel, Estonia, Iceland, Slovak Republic, the Czech
Republic, Poland, Latvia and Hungary is below the OECD average level.

Higher education largely affects national innovation and social progress. Luxembourg, the United States and other countries put more financial resources into tertiary education. Spending on higher education in America is 29,328 dollars. As an education powerful nation and an education dominant country in the world, the universities in the United States are characterized by privatization, and school funding for students is great. This means that the state will pay considerable financial resources in the higher education stage.

On average, the expenditure per student on higher education in OECD countries is 1.8 times higher than that on primary education. However, the pattern of expenditure greatly varies from country to country. The main reason is that education policy in higher education is even more different. For example, spending on higher education in Iceland is only twice as high as that on primary education. However, in the United States, the ratio is up to 2.6 times. 


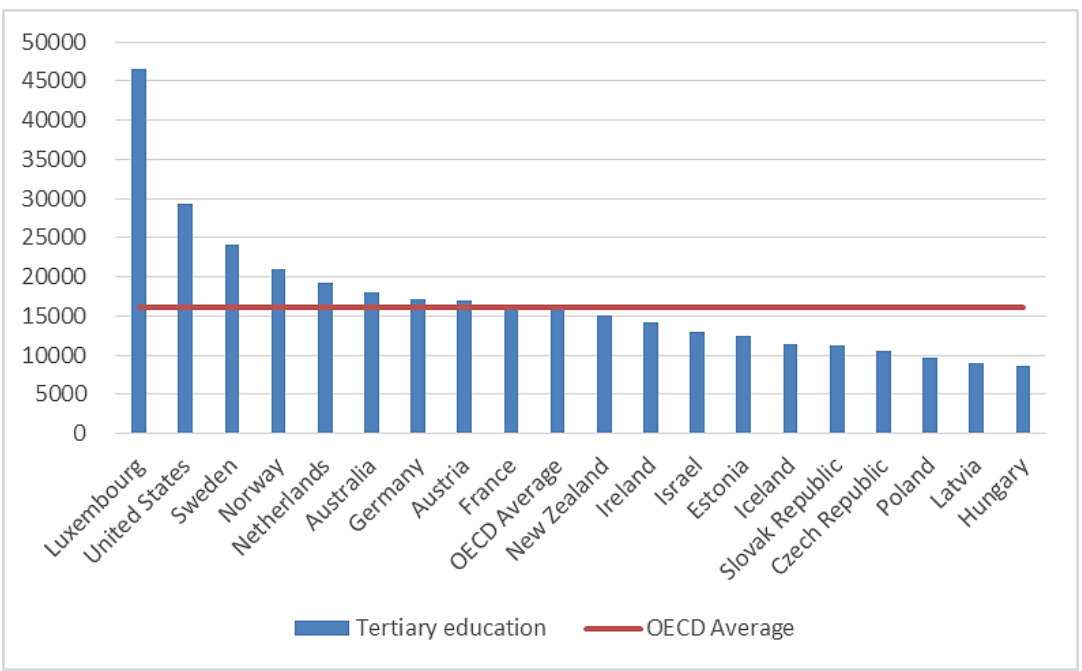

Fig. 5. Sort out annual spending per student on tertiary educational institutions for all services in 2014 .

\section{B. Analysis for Annual Spending per Students on}

\section{Educational Institutions for Different Types of Services}

The annual expenditure per student on educational institutions for different types of services is also from the OECD official publication, Education at a glance: 2017 OECD indicators [7]. According to "Fig. 2", 94\% of total student expenditure per student is spent on core education services at primary education, secondary education and postsecondary non-tertiary education, such as teaching costs (\$ 8,948 per student) and only $6 \%$ for ancillary services, such as student welfare (\$540). In higher education (Differences are even greater in higher education), the ratio of core services is much lower (64\%), and expenditures on research and development activities account for about one third of total expenditure on average.

From 2008 to 2014, the spending per student in education institutions in OECD countries that is in primary education level, secondary education level and post-secondary non- tertiary education level increased by an average of 8 percentage points on average. However, the number of students fell by 2 percentage points, which led to $10 \%$ growth in education spending per student over the same period. Excluding teaching-related activities (research and development as well as ancillary services such as student welfare services). On average, from primary to tertiary education, annual expenditure per student is $\$ 9,189$ in OECD countries.

On average, OECD countries spend around $70 \%$ more per student at tertiary level than at primary, secondary and post-secondary non-tertiary levels combined. [7] The main reason is that $\mathrm{R} \& \mathrm{D}$ activities or ancillary services in tertiary education are an important part of expenditures. These can both account for a significant proportion of expenditure at tertiary level ( $36 \%$ on average). If these items are excluded, expenditure per student on core educational services at tertiary level is still on average $16 \%$ higher than at primary, secondary and post-secondary non-tertiary levels.

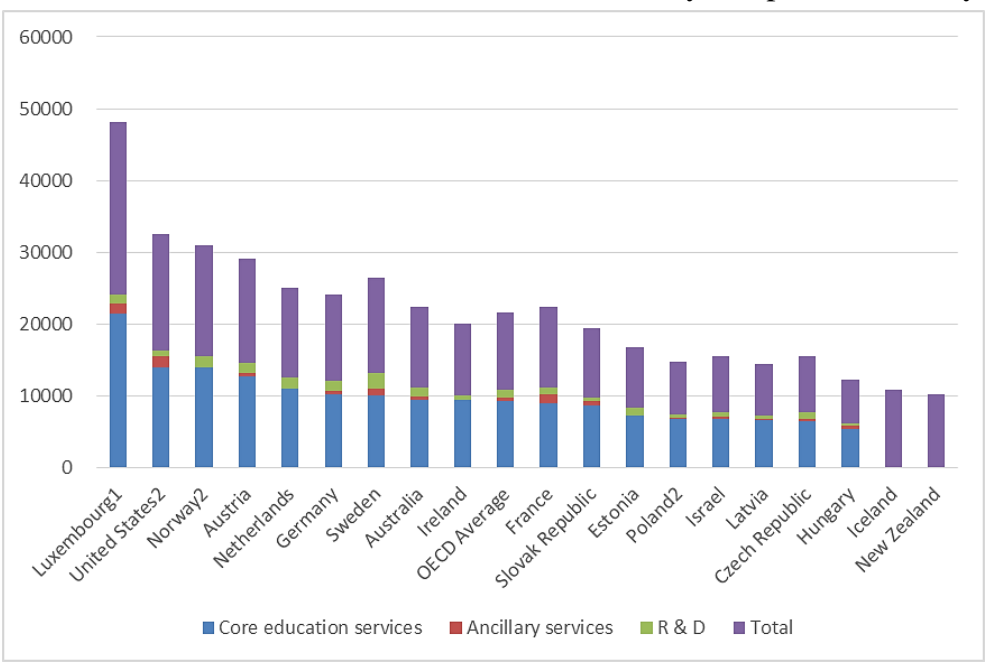

Fig. 6. Annual spending per students on educational institutions for different types of services. 


\section{FINDING AND CONCLUSIONS IN THIS RESEARCH}

According to the above ranking and analysis of annual spending per student on educational institutions for all services and annual expenditure per student on educational institutions for different types of services in all 19 OECD countries, the paper can draw conclusions as following:

First, many countries have invested most of their education funds in tertiary education. Some of them neglect the importance of post-secondary non-tertiary education, which is mainly for train professional and technical personnel that countries need. On average, in almost all countries, expenditure per student on educational institutions increases along with educational level, with exception of post-secondary non-tertiary education, where expenditure per student is lower than in other educational levels on average.

Second, in the primary education level, students are expected to spend an average of six years, which resulting in a total per-student cost of more than $\$ 50,000$ over period. The sum in secondary education is even higher, where students are expected to spend six to seven years, generating a total per-student cost of more than $\$ 70,000$. At the end of primary and secondary studies, students can spend more than $\$ 120,000$ in total expenses. [7] In most countries, primary and secondary education is included in the system of compulsory education, which means that some countries must allocate huge amounts of financial expenditure during the compuls ory education.

\section{CONCLUSION}

Finally, with the increasing pace of modern national competition, regardless of developed and developing countries, they both consider education as the key to economic growth and prosperity of the country. The reason is that education can provide talents and technology for the country. The factors that influence the development of education are complex and different. Undoubtedly, the investment in education is a very important aspect. In order to win the new advantages of international talent competition, all countries are continuously increasing their investment in all kinds of education at all levels. Meanwhile, they strive to promote the fair distribution of educational opportunities and resources. How to make the allocation of educational financial resources more fair and efficient is an important is sue that all countries in the world are facing together.

\section{REFERENCES}

[1] Zhang Guoqiang. Analysis and Inspiration on the Indicator System of OECD Educational Development - A Case Study of Education at A Glance: OECD Indicat ors (2003) [J]. Studies in Foreign Education, 2006, (11):24-28.

[2] Sun Jihong, YANG Xiaojiang. Research on Evolution and Development Trend of OECD Education Indicator System [J]. Modern Education Management, 2009,(05):89-92.

[3] Ding Ying. The Public and Private Expenditure Division on Education: A Comparative Study of the US, UK, Japan, South Korea,
France and Germany [J].Peking University Education Review, 2008, (04):28-37+188

[4] Xu Minjuan. Analysis of Main Educational Indicators in OECD Countries [J]. Contemporary Educational Science, 2011,(03):41-44.

[5] Liao Chuhui. Comparison and Analysis of Educational Expenditure System in Western Developed Countries [J]. Chinese Finance, 2004, (01):64-65.

[6] Zhao Xiang. International Comparison of Educational Expenditure Performance Evaluation [J]. Financial supervision, 2007, (19):62-63.

[7] OECD. Education at a Glance 2017: OECD Indicators [R].Paris: OECD Publishing, 2017: 168-179 http://www.oecdilibrary .org/educat ion/education-at-a-glance-2017/indicator-b1-howmuch-is-spent-per-student_eag-2017-16-en. 